\title{
BHMT Gene
}

National Cancer Institute

\section{Source}

National Cancer Institute. BHMT Gene. NCI Thesaurus. Code C104869.

This gene is involved in homocysteine metabolism. 